University of Nebraska - Lincoln

DigitalCommons@University of Nebraska - Lincoln

Agronomy \& Horticulture -- Faculty Publications

Agronomy and Horticulture Department

2006

\title{
Early-season insect defoliation influences the critical time for weed removal in soybean
}

Travis C. Gustafson

University of Nebraska-Lincoln

Stevan Z. Knezevic

University of Nebraska-Lincoln, sknezevic2@unl.edu

Thomas E. Hunt

University of Nebraska-Lincoln, thunt2@unl.edu

John L. Lindquist

University of Nebraska-Lincoln, jlindquist1@unl.edu

Follow this and additional works at: https://digitalcommons.unl.edu/agronomyfacpub

Part of the Plant Sciences Commons

Gustafson, Travis C.; Knezevic, Stevan Z.; Hunt, Thomas E.; and Lindquist, John L., "Early-season insect defoliation influences the critical time for weed removal in soybean" (2006). Agronomy \& Horticulture -Faculty Publications. 417.

https://digitalcommons.unl.edu/agronomyfacpub/417

This Article is brought to you for free and open access by the Agronomy and Horticulture Department at DigitalCommons@University of Nebraska - Lincoln. It has been accepted for inclusion in Agronomy \& Horticulture -Faculty Publications by an authorized administrator of DigitalCommons@University of Nebraska - Lincoln. 


\section{Early-season insect defoliation influences the critical time for weed removal in soybean}

Travis C. Gustafson

Department of Agronomy and Horticulture,

University of Nebraska, Lincoln, NE 68583

Stevan Z. Knezevic

Corresponding author. Haskell Agricultural

Laboratory, University of Nebraska, 57905866

Road, Concord, NE 68728-2828;

sknezevic2@unl.edu

Thomas E. Hunt

Haskell Agricultural Laboratory, University of

Nebraska, 57905866 Road, Concord NE 687282828

John L. Lindquist

Department of Agronomy and Horticulture,

University of Nebraska, Lincoln, NE 68583

\begin{abstract}
To develop more effective pest-management strategies, it is essential to understand how different pests interact with each other and the crop. Field studies were conducted in 2003 and 2004 at two Nebraska locations to determine the effects of early-season crop defoliation on the critical time for weed removal (CTWR) in narrow-row soybean. Three soybean defoliation levels were selected to simulate 0 , 30 , and $60 \%$ leaf tissue removal by the bean leaf beetle. Weeds were allowed to compete with the crop until V2, V4, V6, R3, and R5 growth stages. There were also season-long weedy and weed-free treatments. Results indicated that the CTWR in soybean occurred earlier as defoliation levels increased from 0 to $60 \%$. The CTWR occurred at V3, V2, and V1 growth stage for 0,30 , and $60 \%$ defoliation levels, respectively. Overall, 60\% defoliation resulted in earlier CTWR by at least 14 $\mathrm{d}$. Yield losses from defoliation and weed interference were primarily associated with a reduction in number of pods per plant ${ }^{-1}$.
\end{abstract}

Nomenclature: Soybean, Glycine max L. Merr.

Key words: Critical time for weed removal, integrated pest management, multiple pests, pest complex, simulated insect defoliation.
Typically, insect- and weed-management practices exist as separate entities to those who develop pest-management strategies. The need for an integrated approach is particularly evident in soybean, where early-season defoliation by bean leaf beetle (Certoma trifurcata Förster) is a common occurrence (Higley and Boethel 1994; Zeiss and Pedigo 1996), along with weed interference. Even though bean leaf beetles may inhabit weedy areas and alfalfa fields around soybeans, they will emigrate into soybean fields soon after crop emergence (Higley and Boethel 1994). Over-wintering adult bean leaf beetles emerge from leaf litter and can begin feeding on the crop as early as $3 \mathrm{~d}$ after soybean emergence (Smelser and Pedigo 1991). Typically, early-season defoliation by bean leaf beetles is not considered economically damaging to soybean (Hammond 1989; Hunt et al. 1994, 1995; Weber and Caldwell 1966) because soybean has enough time in the growing season to recover from bean leaf beetle injury. However, early-season defoliation can delay canopy development and reduce plant height (Hunt et al. 1994), predisposing soybean to economic damage by subsequent stresses (Higley 1988), including weed interference. Delay in canopy development allows more light transmittance, which can favor weed growth and competition directly affecting weed management programs. Others have studied effects of defoliation and weed-interference on soybean during late-season growth (e.g., reproductive growth stages) (Grymes et al. 1999; Helm et al. 1992; Higgins et al. 1984). No research has specifically addressed the impact of early-season insect defoliation on the need for timing of weed control. Many defoliation studies use single-day defoliation techniques to simulate insect injury (Hammond 1989; Talekar and Lee 1988; Weber 1955; Weber and Caldwell 1966). Fewer studies examined defoliation that occurred over several crop growth stages (e.g., from VE to V4 stage) (Fehr and Caviness 1977). Hunt et al. (1994) ex- amined differences between single-day and sequential defoliation methods and reported that sequential defoliation better simulates actual early-season insect injury.

One useful tool for determining timing of POST weed control is the critical period for weed control (CPWC) (Knezevic et al. 2002). The CPWC represents the time interval between two separately measured crop-weed interference components: (1) the critical timing of weed removal (CTWR) - the maximum amount of time early-season weed competition can be tolerated before significant yield reductions occur and (2) the critical weed-free period-the minimum weed-free period required from the time of crop planting to prevent yield loss from late-emerging weeds. The first component was suggested to determine the "beginning" of the CPWC, and the latter determines its "end" (Knezevic et al. 2002). The results from both components are combined to determine the CPWC. Previous research reported that CPWC was affected by nitrogen level in corn (Zea mays L.) (Evans et al. 2003), and row spacing in soybean (Knezevic et al. 2003a, 2003b). The objective of this study was to determine the CTWR for soybean as influenced by varying levels of simulated early-season insect defoliation.

\section{Materials and Methods}

\section{Location Description}

Field trials were conducted in 2003 and 2004 at two locations in eastern Nebraska (Lincoln and Concord). Naturally occurring populations of weeds were allowed to compete with the crop in this experiment, and locations were selected based on historical presence of weeds common to eastern Nebraska. Experimental fields were cultivated before planting to ensure weed emergence occurred within a few days of soybean emergence and to prepare the seedbed for planting. Previous crops included grain sorghum in Lincoln 
for both years and corn for both years in Concord. Soybean was planted in 19-cm-wide rows on 29 May 2003 and 5 June 2003 in Lincoln and Concord, respectively, and 2 June 2004 and 28 May 2004 in Lincoln and Concord, respectively. Asgrow 'AG2703' and Agripro '2502' were the two glyphosate-tolerant and -indeterminate varieties used in Lincoln and Concord, respectively, each year. Different varieties were selected because of the different climate regions of each location. In 2003 a population of 65 and 29 soybean $\mathrm{m}^{-2}$ was established at Lincoln and Concord, respectively, and in 2004, 44 and 34 soybean $\mathrm{m}^{-2}$ at Lincoln and Concord, respectively. Soybean emergence was reduced at Concord in 2003 because of soil crusting after heavy rains before emergence, which prevented canopy closure through the remainder of the growing season.

\section{Experimental Design}

The design was a two-factor split plot with four replications. The main plot factor was leaf defoliation at three levels including 0,30 , and $60 \%$. The subplot factor was increasing duration of weed interference, where weeds were removed at soybean growth stage V2, V4, V6, R3, and R5. Season-long weed-free and weedy treatments were also included.

Each experimental unit was $4.6 \mathrm{~m}$ wide (consisting of 24 rows spaced $19 \mathrm{~cm}$ apart) and $18 \mathrm{~m}$ long. Defoliation and destructive sampling was done within the center eight rows of each experimental unit with the remaining rows maintained as buffer to eliminate edge effects. Two meters at each end of each plot also were left undisturbed. Final yield was harvested by hand from $4 \mathrm{~m}$ of eight defoliated soybean rows in each experimental unit at physiological maturity. Grain samples were dried and weighed to determine yield. Additionally, 10 soybean plants were harvested from the harvest area to determine yield components. Pods and seeds were counted and seeds were weighed from the 10 plants in each plot. Soybean yield components considered in this study consisted of number of pods per plant, number of seeds per pod, and seed weight.

\section{Field Procedures}

\section{Sequential Defoliation}

Simulated soybean defoliation initiated at the late VC stage when unifoliate leaves were fully unfolded and ended at the V2 stage with the third trifoliate leaf fully unfolded. Soybeans were manually defoliated for approximately $8 \mathrm{~d}$ adopting previously established methods (Hunt et al. 1994). Each day for $8 \mathrm{~d}$ one leaflet was removed from each soybean plant for plots receiving the $60 \%$ defoliation treatment. One leaflet was removed every $2 \mathrm{~d}$ for $30 \%$ defoliated soybean plots. Defoliation was initiated on June 17, 2003, and June 22, 2004, and stopped on June 25, 2003, and June 28, 2004, at Lincoln. At Concord, defoliation was initiated on June 27, 2003, and June 21, 2004, terminating on July 2, 2003, and June 28, 2004.

\section{Weed Removal}

A natural community of weed species was allowed to interfere with the soybean crop until predetermined removal times according to the soybean growth stage in undefoliated weed-free plots. Weed population and species composition varied throughout all locations and years. A backpack sprayer charged with $\mathrm{CO}_{2}$ was used to make applications of a commercial formulation of glyphosate ${ }^{1}$ with a total spay volume of $187 \mathrm{~L} \mathrm{ha}^{-1}$. Subsequent applications of glyphosate were performed in plots exhibiting secondary flushes of weeds.

\section{Data Analysis}

Relative crop yield was calculated as the percentage of weed-free undefoliated soybean yield to take into account yield loss from both defoliation and duration of weed interference. The effect of years, locations, defoliation levels, weed removal times (RT), and their interactions on yield and yield components were evaluated based on ANOVA with the use of PROC MIXED in SAS ${ }^{2}$ version 8.0 (Littell et al. 1996). Fixed effects were replication, defoliation, duration of weed interference, year, location, and their relevant interactions. Random effects were replication by defoliation interactions. All data were separated by location and year unless otherwise noted due to significant location by year interactions $(\mathrm{P}<0.05)$. If the defoliation level by $\mathrm{RT}$ interaction was not significant, further analysis was conducted with the use of main-effect treatment least-squares means.

To determine the CTWR, a mixed-model nonlinear regression analysis was performed with the use of PROC NLMIXED in SAS. Relative yields were fit to a three-parameter logistic equation as a function of increasing duration of weed interference based on the procedure outlined by Knezevic et al. (2002):

$$
\mathrm{RY}=(1 /[\exp \{k(T-d)\}+f]+[\{f-1 / f\}]) \times 100,
$$

where RY was relative yield, $d$ is the point of inflection on the $x$ axis, $k$ and $f$ are constants, and $T$ is the duration of weed interference calculated as thermal time in growing degree days after crop emergence. GDD were calculated with the use of a base temperature of $10 \mathrm{C}$ and maximum temperature of $30 \mathrm{C}$ with the use of local weather data obtained from the High Plains Regional Climate Center. All CTWR calculations in this study were based on an acceptable yield loss of 5\%, although the CTWR for any other levels of yield loss can be calculated from the equation parameters presented.

Parameter estimates from Equation 1 were analyzed for differences between defoliation treatments using a $t$-test $(\alpha=$ 0.05 ) in PROC NLMIXED to determine if defoliation and weed interference influenced relative yield in soybeans. For yield component analysis, the relative number of pods per plant was calculated in a similar manner to relative yield, and Equation 1 was fit to the data, substituting relative pods per plant for RY.

\section{Results and Discussion}

Soybean emergence occurred on June 9, 2003, and June 8, 2004, in Lincoln and June 16, 2003, and June 7, 2004, in Concord. Weed emergence coincided with soybean emergence in all location-years except Lincoln in 2004, when weed emergence occurred approximately $2 \mathrm{~d}$ after soybean emergence. Weeds present included velvetleaf (Abutilon theo- 
TABLE 1. Weed species composition and density at Lincoln and Concord over two years.

\begin{tabular}{|c|c|c|c|}
\hline Location & Year & Species & $\begin{array}{c}\text { Density } \\
\text { (plants } \mathrm{m}^{-2} \text { ) }\end{array}$ \\
\hline \multirow[t]{8}{*}{ Lincoln } & 2003 & Amaranthus spp. & 70 \\
\hline & & Abutilon theophrasti & 33 \\
\hline & & Helianthus annuus & 31 \\
\hline & 2004 & Amaranthus spp. & 8 \\
\hline & & Abutilon theophrasti & 7 \\
\hline & & Helianthus annuus & 2 \\
\hline & & Chenopodium album & 2 \\
\hline & & Setaria spp. & 2 \\
\hline \multirow[t]{7}{*}{ Concord } & 2003 & Setaria spp. & 114 \\
\hline & & Abutilon theophrasti & 41 \\
\hline & & Amaranthus spp. & 29 \\
\hline & 2004 & Setaria spp. & 21 \\
\hline & & Abutilon theophrasti & 17 \\
\hline & & Amaranthus spp. & 13 \\
\hline & & Solanum ptycanthum & 5 \\
\hline
\end{tabular}

phrasti Medicus), common sunflower (Helianthus annuus L.), waterhemp species (Amaranthus spp.), and foxtail species (Setaria spp.) (Table 1).

In 2003, Lincoln received $410 \mathrm{~mm}$ of rainfall; $235 \mathrm{~mm}$ fell before the initiation of defoliation. In 2004, Lincoln received $388 \mathrm{~mm}$ with $190 \mathrm{~mm}$ precipitation before defoliation. In 2003 and 2004, Concord received $175 \mathrm{~mm}$ and $137 \mathrm{~mm}$ rainfall, respectively, with less than half occurring before defoliation in 2003 and more than half occurring before defoliation in 2004 (Table 2).

Actual defoliation levels were determined the day after simulated defoliation terminated by calculating leaf area per plant in defoliated plots and comparing it to leaf area per plant in undefoliated plots. Actual defoliation levels ranged from 24 to $45 \%$ leaf area reduction for the $30 \%$ defoliation level and 51 to $70 \%$ leaf area reduction for the $60 \%$ defoliation level. These data confirmed that each location-year had three separate levels of defoliation.

\section{Soybean-Yield Response to Defoliation}

Yields varied among locations and years. Defoliation reduced yields in weed-free soybean at both locations in 2004,

TABLE 2. Mean daily temperature (C) and total precipitation (mm) at Lincoln, NE and Concord, NE in 2003 and 2004.

\begin{tabular}{lrrrrr}
\hline & \multicolumn{2}{c}{ Lincoln } & & \multicolumn{2}{c}{ Concord } \\
\cline { 2 - 3 } \cline { 5 - 6 } & 2003 & 2004 & & 2003 & 2004 \\
\hline Temperature (C) & & & & & \\
May & 16 & 18 & & 14 & 15 \\
June & 21 & 21 & 20 & 19 \\
July & 26 & 23 & & 23 & 21 \\
August & 25 & 22 & & 23 & 19 \\
September & 20 & 22 & 19 & 20 \\
October & 13 & 13 & 11 & 10 \\
Precipitation (mm) & & & & \\
May & 68 & 119 & 86 & 116 \\
June & 167 & 71 & & 44 & 49 \\
July & 26 & 131 & 73 & 59 \\
August & 33 & 45 & 17 & 15 \\
September & 92 & 13 & 39 & 15 \\
October & 25 & 10 & 18 & 17 \\
\hline
\end{tabular}

TABLE 3. Soybean yields as influenced by defoliation and weed interference at Lincoln and Concord in 2003 and 2004.

\begin{tabular}{|c|c|c|c|c|}
\hline Location & Year & $\begin{array}{c}\text { Defoliation } \\
\text { level }\end{array}$ & $\begin{array}{l}\text { Weed } \\
\text { free }^{a}\end{array}$ & Weedy $^{a}$ \\
\hline & & & $\left(\mathrm{kg} \mathrm{ha}^{-1}\right)$ & $\left(\mathrm{kg} \mathrm{ha}^{-1}\right)$ \\
\hline \multirow[t]{6}{*}{ Lincoln } & 2003 & $0 \%$ & $2,131 \mathrm{a}$ & $94 \mathrm{a}$ \\
\hline & & $30 \%$ & $2,062 \mathrm{a}$ & $77 \mathrm{a}$ \\
\hline & & $60 \%$ & $1,926 \mathrm{a}$ & $56 a$ \\
\hline & 2004 & $0 \%$ & $3,538 \mathrm{a}$ & $3,013 \mathrm{a}$ \\
\hline & & $30 \%$ & $3,402 \mathrm{a}$ & $2,467 \mathrm{a}$ \\
\hline & & $60 \%$ & $2,751 \mathrm{~b}$ & $2,530 \mathrm{a}$ \\
\hline \multirow[t]{6}{*}{ Concord } & 2003 & $0 \%$ & $2,024 \mathrm{a}$ & $59 a$ \\
\hline & & $30 \%$ & $1,895 \mathrm{a}$ & $82 \mathrm{a}$ \\
\hline & & $60 \%$ & $1,859 \mathrm{a}$ & $57 a$ \\
\hline & 2004 & $0 \%$ & $2,817 \mathrm{a}$ & $1,412 \mathrm{a}$ \\
\hline & & $30 \%$ & $2,433 \mathrm{ab}$ & 871 b \\
\hline & & $60 \%$ & $2,216 \mathrm{~b}$ & $602 \mathrm{~b}$ \\
\hline
\end{tabular}

a Different letters following yields indicate significant differences $(\mathrm{P}<$ 0.05 ) between defoliation levels at each location-year.

but it did not reduce weed-free yields in 2003 (Table 3). Water stress after defoliation at Lincoln in 2003 had the highest impact on crop yield, reducing the difference between the defoliation levels. Weed-free yields in 2003 ranged from 1,926 to $2,131 \mathrm{~kg} \mathrm{ha}^{-1}$ at Lincoln, and 1,859 to 2,024 $\mathrm{kg} \mathrm{ha}^{-1}$ at Concord. Weed-free yields were $3,538 \mathrm{~kg} \mathrm{ha}^{-1}$ for soybean receiving no defoliation, $3,402 \mathrm{~kg} \mathrm{ha}^{-1}$ for $30 \%$, and $2,751 \mathrm{~kg} \mathrm{ha}^{-1}$ for $60 \%$ defoliated soybean at Lincoln in 2004. At Concord weed-free yields were 2,817, 2,433, and 2,216 $\mathrm{kg} \mathrm{ha}^{-1}$ for 0,30 , and $60 \%$ defoliated soybean, respectively. Soybean yields in season-long weedy plots were significantly influenced by defoliation level only at Concord in 2004 (Table 3). This lack of difference at the other location-years in crop yields is likely a result of the combination of defoliation and season-long competition from weeds.

TABLE 4. The critical time for weed removal at Lincoln and Concord for 2003 and 2004 on the basis of days after crop emergence, growing degree days (GDD) after crop emergence, and corresponding crop growth stage when weeds must be removed.

\begin{tabular}{lccccc}
\hline & & & \multicolumn{3}{c}{ Critical time for weed removal } \\
\cline { 4 - 6 } Location & Year & $\begin{array}{c}\text { Defoliation } \\
\text { level }\end{array}$ & $\begin{array}{c}\text { Days after } \\
\text { emergence }\end{array}$ & $\begin{array}{c}\text { GDD after } \\
\text { emergence }\end{array}$ & $\begin{array}{c}\text { Crop } \\
\text { growth stage }\end{array}$ \\
\hline Lincoln & \multirow{2}{*}{2003} & $0 \%$ & 22 & $476 \mathrm{a}$ & $\mathrm{V} 3$ \\
& & $30 \%$ & 17 & $368 \mathrm{a}$ & $\mathrm{V} 2$ \\
& & $60 \%$ & 6 & $112 \mathrm{~b}$ & Unifol. \\
& \multirow{2}{*}{2004} & $0 \%$ & 43 & $921 \mathrm{a}$ & V6 \\
& & $30 \%$ & 36 & $744 \mathrm{a}$ & V5 \\
& & $60 \%$ & 2 & $51 \mathrm{~b}$ & Unifol. \\
Concord & 2003 & $0 \%$ & 20 & $427 \mathrm{a}$ & V3 \\
& & $30 \%$ & 8 & $187 \mathrm{ab}$ & V2 \\
& & $60 \%$ & 6 & $127 \mathrm{~b}$ & Unifol. \\
& \multirow{2}{*}{2004} & $0 \%$ & 25 & $414 \mathrm{a}$ & V3 \\
& & $30 \%$ & 6 & $139 \mathrm{~b}$ & V2 \\
& & $60 \%$ & 3 & $78 \mathrm{~b}$ & Unifol. \\
\hline
\end{tabular}

${ }^{a}$ Different letters following GDD after emergence values indicate significant $(\mathrm{P}<0.05)$ differences between defoliation levels within each locationyear. 

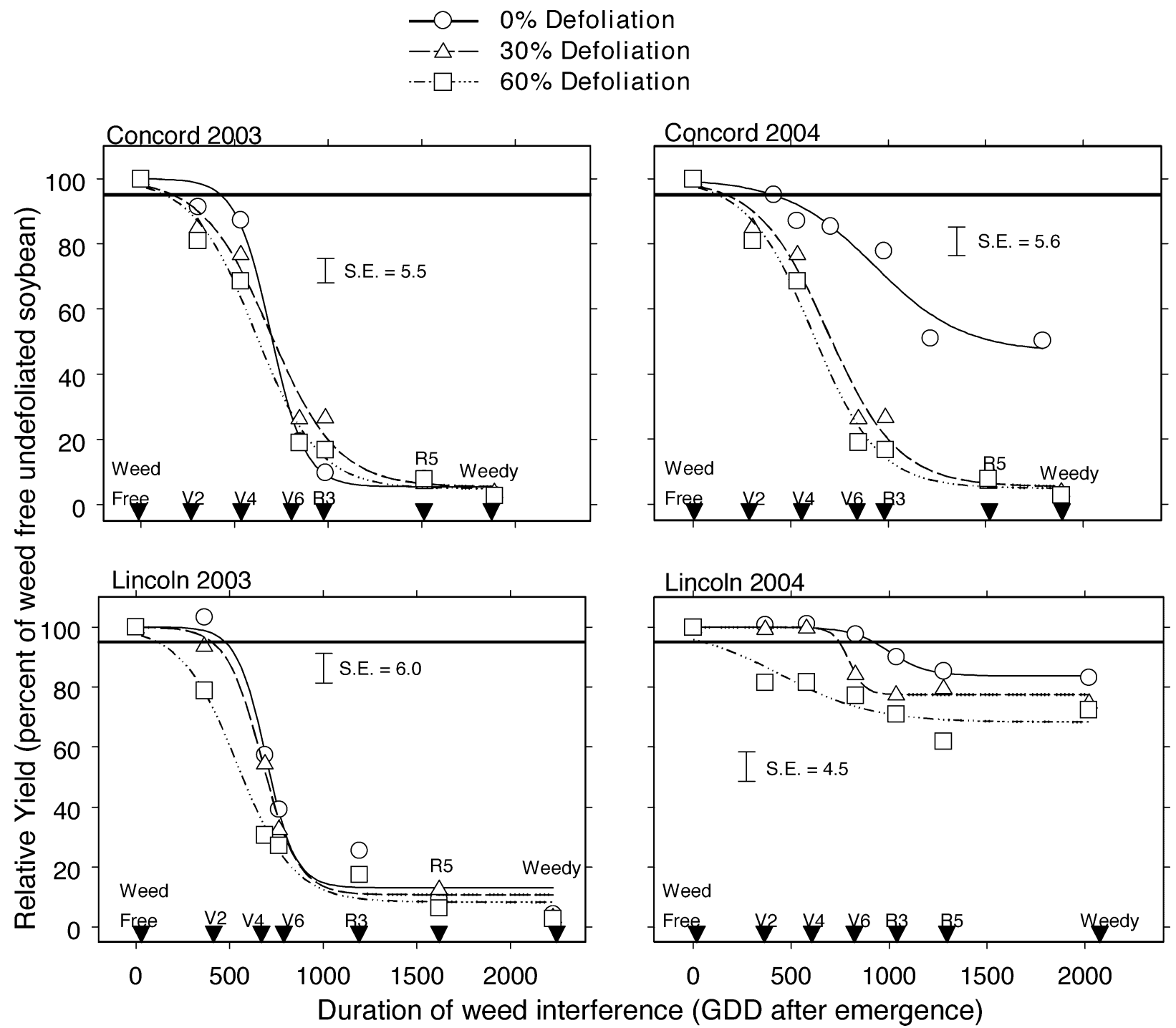

FIGURE 1. Soybean relative yield as a function of duration of weed interference (Equation 1) for three defoliation levels at Lincoln and Concord in 2003 and 2004. Parameter estimates for each regression are shown in Table 5. The critical time for weed removal is the value on the $x$ axis where the acceptable yield loss line of $5 \%$ intersects the relative yield curve.

TABLE 5. Parameter estimates for relative yield as influenced by duration of weed interference (Figure 1) at Lincoln and Concord in 2003 and 2004 .

\begin{tabular}{|c|c|c|c|c|c|}
\hline \multirow[b]{2}{*}{ Location } & \multirow[b]{2}{*}{ Year } & \multirow{2}{*}{$\begin{array}{l}\text { Defoliation } \\
\text { level }\end{array}$} & \multicolumn{3}{|c|}{ Parameter estimates $(\mathrm{SE})^{\mathrm{a}, \mathrm{b}}$} \\
\hline & & & $K$ & $D$ & $F$ \\
\hline \multirow[t]{6}{*}{ Lincoln } & 2003 & $0 \%$ & $0.013(0.006) \mathrm{a}$ & $683.4(26.2) \mathrm{a}$ & $1.15(0.05) \mathrm{a}$ \\
\hline & & $30 \%$ & $0.010(0.003) \mathrm{a}$ & $651.3(36.1) \mathrm{a}$ & $1.12(0.05) \mathrm{a}$ \\
\hline & & $60 \%$ & $0.007(0.001) \mathrm{a}$ & $527.9(34.8) \mathrm{b}$ & $1.09(0.04) \mathrm{a}$ \\
\hline & 2004 & $0 \%$ & $0.010(0.010) \mathrm{a}$ & $824.2(167.2) \mathrm{a}$ & $6.17(1.36) \mathrm{a}$ \\
\hline & & $30 \%$ & $0.025(0.147) \mathrm{a}$ & $734.5(542.6) a b$ & $4.45(0.49) \mathrm{a}$ \\
\hline & & $60 \%$ & $0.004(0.001) \mathrm{a}$ & $174.1(120.2) \mathrm{b}$ & $3.16(0.31) b$ \\
\hline \multirow[t]{6}{*}{ Concord } & 2003 & $0 \%$ & $0.011(0.002) \mathrm{a}$ & $687.1(29.8) \mathrm{a}$ & $1.06(0.03) \mathrm{a}$ \\
\hline & & $30 \%$ & $0.006(0.001) \mathrm{b}$ & $682.6(37.9) \mathrm{a}$ & $1.06(0.04) \mathrm{a}$ \\
\hline & & $60 \%$ & $0.006(0.001) \mathrm{b}$ & $604.7(35.6) \mathrm{a}$ & $1.05(0.04) \mathrm{a}$ \\
\hline & 2004 & $0 \%$ & $0.004(0.001) \mathrm{a}$ & $784.0(98.4) \mathrm{a}$ & $1.88(0.2) \mathrm{a}$ \\
\hline & & $30 \%$ & $0.003(0.001) \mathrm{a}$ & $1023.6(197.1) \mathrm{a}$ & $1.24(0.2) \mathrm{b}$ \\
\hline & & $60 \%$ & $0.004(0.001) \mathrm{a}$ & $642.2(64.5) \mathrm{a}$ & $1.27(0.1) \mathrm{b}$ \\
\hline
\end{tabular}

a Different letters after each estimate indicate significant $(\mathrm{P}<0.05)$ differences between defoliation levels within each location-year.

${ }^{b} \mathrm{D}$ is the point of inflection on the $\mathrm{x}$-axis, $\mathrm{K}$ and $\mathrm{F}$ are constants (equation 1). 
Concord 2003
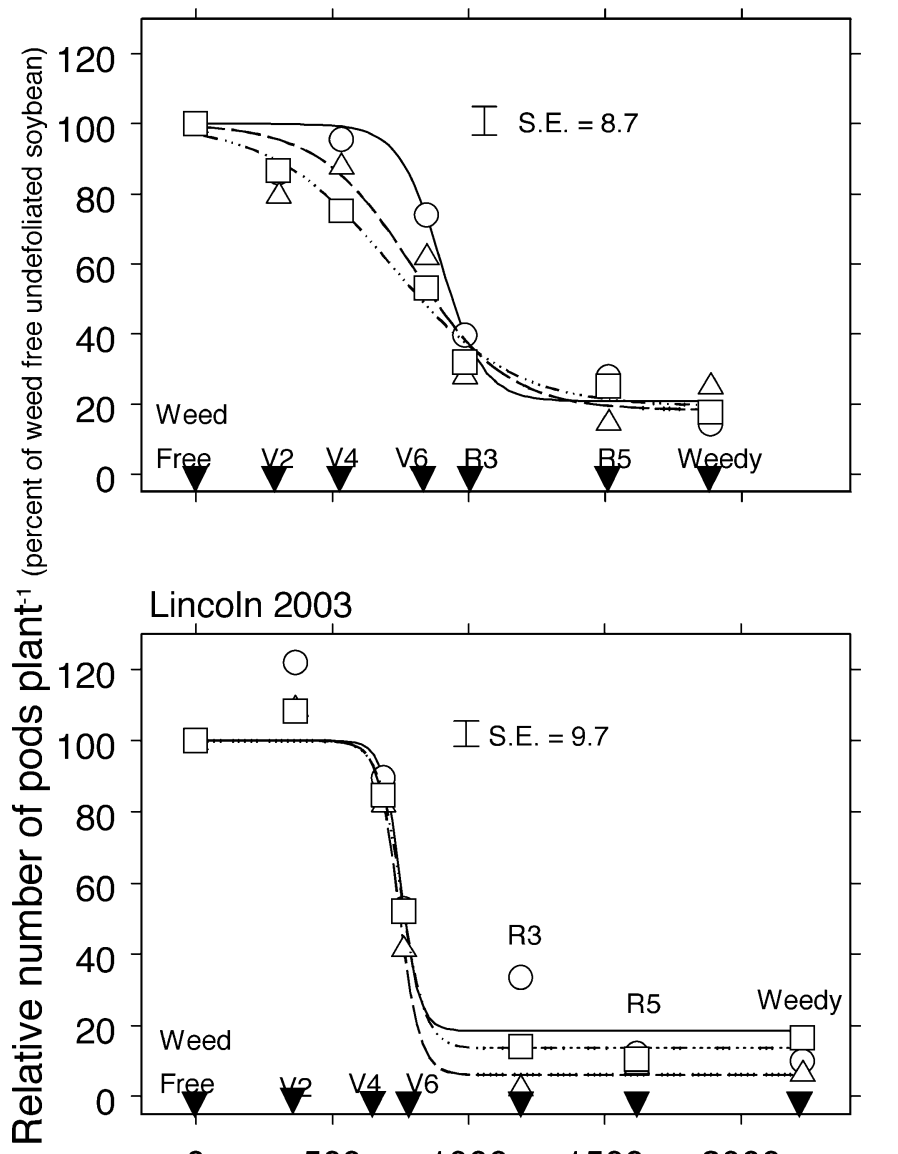

Concord 2004

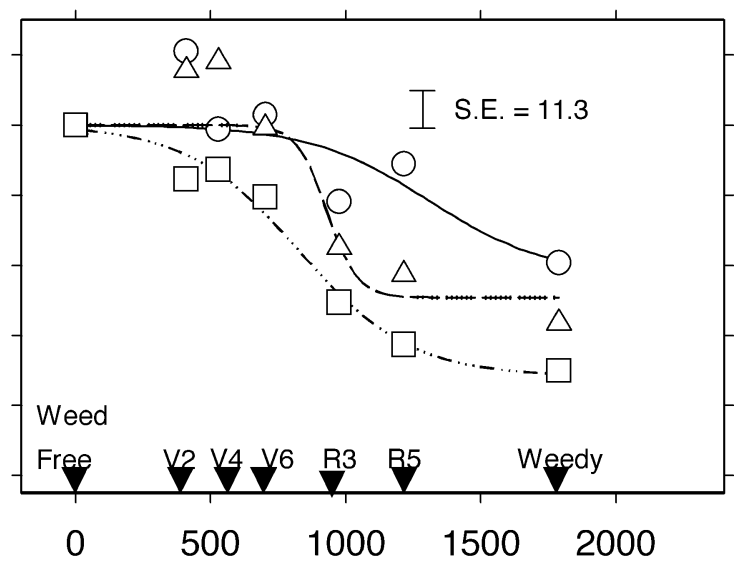

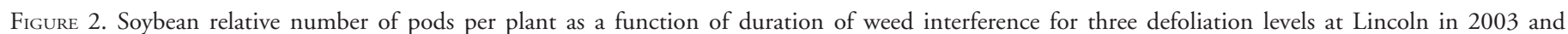
Concord in 2003 and 2004. Parameter estimates are located in Table 6.

\section{Critical Time for Weed Removal}

Defoliation level influenced the CTWR at all locationyear combinations. Without defoliation, the CTWR for 3 of 4 location-years occurred at about 440 GDD after emergence, or the V3 crop growth stage (Table 4). This is consistent with results of Knezevic et al. (2003a), who reported that the CTWR in soybeans planted in 19-cm rows occurred at the V3 to V4 crop growth stage. The CTWR for $30 \%$ and $60 \%$ defoliation occurred at about 230 (V2) and 105 (V1) GDD after emergence, respectively (Figure 1) at three of four location-years. The CTWR at Lincoln in 2004 occurred at V6 in undefoliated soybean due to lower weed density (Table 2) than the other location-years, indicating that CTWR is influenced by weed density (Knezevic et al. 2002). The CTWR at Lincoln in 2003 was 5 and $16 \mathrm{~d}$ earlier for $30 \%$ and $60 \%$ defoliated soybean, respectively, when compared to undefoliated soybean. In contrast, at Concord in 2004 the CTWR occurred 19 and 22 days earlier for $30 \%$ and $60 \%$ defoliation levels (Table 4). Regression parameters are presented in Table 5 . The difference in CTWR between defoliation levels indicated that defoliation can impact the need for timing of weed removal, and directly affects weed-management practices in soybean. Generally, when a high level of defoliation was present, the CTWR occurred at the earlier growth stages of the crop.
Although this study examined the effects of simulated insect defoliation on CTWR of soybean, the results of this study may not necessarily be applied to other forms of earlyseason defoliation, such as hail damage. Although the defoliation approach used in this research accurately simulates insect defoliation, it does not accurately represent hail damage. Hail particles (ice) not only defoliate, but also rip leaf tissue and cause stem breakage and bruising (Fehr et al. 1983), whereas typical insect defoliation results simply in gross leaf tissue removal. Also, hail injury occurs as a singleday event, while insect defoliation occurs gradually over time. Therefore, differences in injury type will likely cause differential crop responses and different CTWR. However, a study needs to be conducted to test such a hypothesis.

\section{Yield Components}

Defoliation did not affect soybean plant density measured throughout the growing season (data not shown) or the weight of 100 seeds (data not shown), but it reduced the number of pods per plant and in some cases had varying effects on seed number per pod. Dry weights of 100 seeds in weed-free plots were 11 and $12 \mathrm{~g}$ at Concord and Lincoln in 2003, respectively, and 13 and $15 \mathrm{~g}$ at Concord and Lincoln in 2004, respectively. Seed number per pod differed 
TABLE 6. Parameter estimates for relative number of pods per plant as influenced by duration of weed interference (Figure 2) at Lincoln in 2003 and Concord in 2003 and 2004.

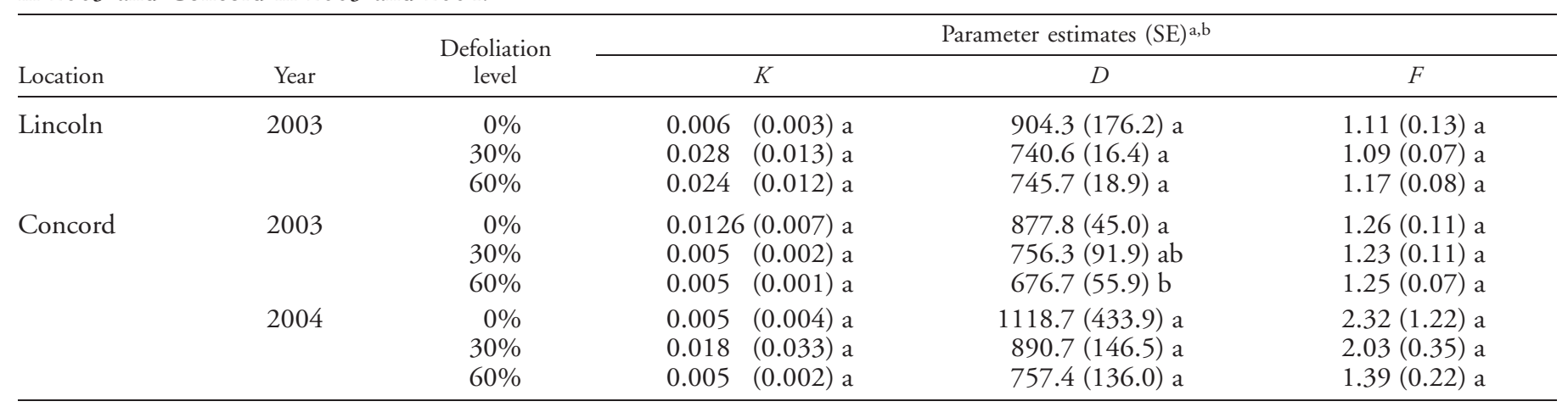

a Different letters after each estimate indicate significant $(\mathrm{P}<0.05)$ differences between defoliation levels within each location-year.

${ }^{b} \mathrm{D}$ is the point of inflection on the $\mathrm{x}$-axis, $\mathrm{K}$ and $\mathrm{F}$ are constants (equation 1).

only in season-long weedy plots at two of the four locationyears. The 30\% defoliation treatment increased the number of seeds per pod in weedy soybean by one seed pod at Concord in 2003 , and the $30 \%$ and $60 \%$ defoliation levels decreased the number of seeds per pod by 0.5 for both defoliation levels in weedy soybean at Concord in 2004.

Number of pods per plant varied among locations and years in weed-free soybean, whereas defoliation consistently reduced relative number of pods per plant in weedy plots. Data for Lincoln in 2004 are not presented because the nonlinear regression model used throughout this study could not be fit to the data. The relationship between relative number of pods per plant and time of weed removal (in GDD) (Figure 2) was similar to that for the CTWR (Figure 1 ), suggesting that the number of pods per plant was the most vulnerable yield component to weed presence. The parameters in Table 6 were only significantly different at Concord in 2003; however, the number of pods per plant was the yield component that most closely matched the yield response curves from defoliation and weed interference from other location-years.

Overall, results from this study indicated that canopy defoliation reduced early-season tolerance of soybean to weeds and, consequently, resulted in earlier CTWR. Board and Tan (1995) reported that a reduction in the number of pods per plant was the primary cause of yield reduction in defoliated soybean. Our results also indicate that the number of pods per plant was the yield component most affected by defoliation and duration of weed interference.

\section{Management Implications}

This study confirmed that the insect-induced defoliation of soybean canopy significantly influenced crop-weed interference relationships. These results suggest that weeds should not be allowed to compete with soybean that is under any defoliation stress, at least for the species combinations and environmental conditions under which these experiments were conducted. The differences in the CTWR documented in this study highlight the importance of integrating decisions regarding the control of defoliating insects and the timing of weed control.

Practical implication of this study is that soybean canopy defoliation reduces early-season crop tolerance to weeds, thus requiring earlier weed management practices than in undefoliated crop. Data presented also suggest the need to monitor bean leaf beetle populations early in the season and weed density to design appropriate pest-management practices to protect the crop. For example, early-season control of insects can enhance crop tolerance to weed presence and vice versa, or simultaneous control of both pests may be needed. In practical terms it means that tank-mixing an insecticide and herbicide in a single application may be necessary.

\section{Sources of Materials}

${ }^{1}$ Glyphosate, Roundup Weathermax, Monsanto Company, 800 North Lindbergh Boulevard, St. Louis, MO 63167.

2 SAS version 8.0, Statistical Analysis Systems Institute, SAS Campus Drive, Cary, NC 27512.

\section{Acknowledgments}

Published as University of Nebraska Agricultural Research Division Journal Series No. 14537. A special thanks is extended to the Nebraska Soybean Board for providing funding for this research. Also, special gratitude to Jerry Echtenkamp, Jon Scott, Ray Brentlinger, Doug Miller, Kevin Horky, Shawn Hock, and numerous student workers for assisting in plot maintenance and data collection.

\section{Literature Cited}

Board, J. E. and Q. Tan. 1995. Assimilatory capacity effects on soybean yield components and pod number. Crop Sci. 35:846-851.

Evans, S. P., S. Z. Knezevic, J. L. Lindquist, C. A. Shapiro, and E. E. Blankenship. 2003. Nitrogen application influences the critical period for weed control in corn. Weed Sci. 51:408-417.

Fehr, W. R. and C. E. Caviness. 1977. Stages of soybean development. Ames, IA: Cooperative Extension Service, Iowa State University, Special Report 80.

Fehr, W. R., D. R. Hicks, S. E. Hawkins, and J. H. Ford. 1983. Soybean recovery from plant cutoff, breakover, and defoliation. Agron. J. 75: $512-515$.

Grymes, C. F., J. L. Griffin, D. J. Boethel, R. R. Leonard, D. L. Jordan, and J. S. Russin. 1999. Soybean response to weed interference and defoliation. Weed Sci. 47:90-94.

Hammond, R. B. 1989. Effects of leaf removal at growth stage V1 on yield and other growth parameters. J. Kans. Entomol. Soc. 62:96-102.

Helm, C. G., M. Kogan, D. W. Onstad, L. M. Wax, and M. R. Jeffords. 1992. Effects of velvetleaf competition and defoliation by soybean looper (Lepidoptera: Noctuidae) on yield of indeterminate soybean. J. Econ. Entomol. 85:2433-2439.

Higgins, R. A., L. P. Pedigo, and D. W. Staniforth. 1984. Effect of velvetleaf 
competition and defoliation simulating green cloverworm (Lepidoptera: Noctuidae) outbreak in Iowa on indeterminate soybean yield, yield components, and economic decision levels. Environ. Entomol. 13:917-925.

Higley, L. G. 1988. Plant and stand response to early season insect-induced stress in a model system. Ph.D. dissertation. Iowa State University, Ames, IA.

Higley, L. G. and D. J. Boethel (eds.). 1994. Handbook of soybean insect pests. College Park, MD: Entomological Society of America.

Hunt, T. E., L. G. Higley, and J. F. Witkowski. 1994. Soybean growth and yield after simulated bean leaf beetle injury to seedlings. Agron. J. 86: $140-146$.

Hunt, T. E., L. G. Higley, and J. F. Witkowski. 1995. Bean leaf beetle injury to seedling soybean: consumption, effects of leaf expansion, and economic injury levels. Agron. J. 87:183-188.

Knezevic, S. Z., S. P. Evans, E. E. Blankenship, R. C. Van Acker, and J. L. Lindquist. 2002. Critical period for weed control: the concept and data analysis. Weed Sci. 50:773-786.

Knezevic, S. Z., S. P. Evans, and M. Mainz. 2003a. Row spacing influences the critical timing for weed removal in soybean (Glycine max). Weed Technol. 17:666-673.
Knezevic, S. Z., S. P. Evans, and M. Mainz. 2003b. Yield penalty due to delayed weed control in corn and soybean. Crop Management. doi:10.1094/CM2003-0219-01-RS. http://www.plantmanagementnetwork.org/pub/cm/ research/2003/delay/.

Littell, R. C., G. A. Milliken, W. W. Stroup, and R. D. Wolfinger. 1996. SAS ${ }^{\circledR}$ System for Mixed Models. Cary, NC: Statistical Analysis Systems Institute. 633 p.

Smelser, R. B. and L. P. Pedigo. 1991. Phenology of Cerotoma trifurcata on soybean and alfalfa in central Iowa. Environ. Entomol. 20:514-519.

Talekar, N. S. and H. R. Lee. 1988. Response of soybean to foliage loss in Taiwan. J. Econ. Entomol. 81:1363-1368.

Weber, C. R. 1955. Effects of defoliation and topping simulating hail injury to soybeans. Agron. J. 47:262-266.

Weber, C. R. and B. E. Caldwell. 1966. Effects of defoliation and stem bruising on soybeans. Crop Sci. 6:25-27.

Zeiss, M. R. and L. P. Pedigo. 1996. Timing of food plant availability: effect on survival and oviposition of the bean leaf beetle (Coleoptera: Chrysomelidae). Environ. Entomol. 25:295-302.

Received June 9, 2005, and approved January 25, 2006. 